\title{
Public libraries: Places creating social capital?
}

\author{
Andreas Vårheim, University of Tromsø \\ Accepted Author Manuscript (post-print) \\ of
}

Vårheim, A. (2009). Public libraries: places creating social capital? Library Hi Tech, 27(3), 372-381. doi:10.1108/07378830910988504

\begin{abstract}
Purpose - The purpose of this paper is to show why studies of public libraries, regarding their possible contribution in creating social capital, are important for social capital research in general, and are important for library practice in particular.

Design/methodology/approach - Building on the latest theoretical developments and empirical findings of social capital research, the role of the public library as a potential creator of social capital is discussed. Findings from both quantitative and qualitative empirical research are discussed, and also the need for further studies is presented.

Findings - The paper reports quantitative macro-level results concerning whether public library expenditure can contribute in explaining social trust patterns in the OECD countries. However, to be able to ascertain this, numerous qualitative studies revealing the mechanisms actually generating generalized trust are needed. Preliminary qualitative interviews suggest that this approach can prove fruitful. Research limitations/implications - The implications for further research into public libraries and the building of generalized trust are twofold: one the one hand, more specific research questions on the role libraries can be asked regarding accommodating diversity and increasing trust among diverse groups, e.g. immigrants.
\end{abstract}


On the other hand, the suitability of the public library for investigating these questions makes the results relevant for social capital research in general.

Practical implications - The library profession points to the importance of libraries for social capital and maintain that libraries have been overlooked in this matter. Strong sentiments like this should be ideal for implementation of research based library policies, strategies and activities for creating social capital.

Originality/value - What is new in this research is that studies of public libraries may contribute in resolving the impasse within contemporary social capital research where neither institutional nor societal perspectives seem to be able to verify how social capital is created.

Keywords: Public libraries, Social capital Paper type: Research paper

\section{Introduction}

According to librarians, public libraries create social capital and trust in most people. According to theories on the creation of social capital, this might well be true. However, there is little research confirming this. Overall, social capital theory is in an impasse regarding what factors generate social capital or generalized trust. Is it universalistic public institutions, voluntary associations, or is it interaction between people? From the point of view of social capital theory, public libraries are interesting cases because libraries are both universalistic institutions and social meeting places. In libraries, both mechanisms for generating social capital can be studied. Preliminary findings suggest that public libraries create social capital both ways. Thus, the specific ways libraries can create social 
capital can have implications for social capital theory as well as for library practice.

As open places, public libraries have potential for accommodating diversity in patrons, for contributing in promoting trusting relationships between diverse people, and as a result of this learning process create trust towards people in general (Audunson, Vårheim, Aabø and Holm 2007; Vårheim 2007a, b; Vårheim, Steinmo and Ide 2008). Diversity in race and ethnicity, economic inequality, corruption, and non-universal welfare services are among the variables creating greatest distrust between people and decrease the amount of social capital in society (Uslaner 2002; Rothstein and Uslaner 2005; Uslaner 2006; Putnam 2007; Rothstein and Stolle 2008). Social capital understood as generalized trust is very unevenly distributed globally. Trust in fellow citizens is not what most people experience in their daily lives. Only in four of the Nordic countries, in the Netherlands, and in China, ${ }^{1}$ a majority of the population think that most people can be trusted (averages over the four waves of the World Values Survey (19812004)) (World Values Survey 2006).

\footnotetext{
${ }^{1}$ Some scholars do not trust the Chinese trust figures. Uslaner (2002:220) and Bjørnskov (2006) argue that the Chinese results should be excluded because they represent an outlier. However, Chen and Lu (2007), in their study of social capital in urban China find that the level of generalized trust is high, and that generalized trust has the same meaning in both the Western and Chinese context. Therefore, these researchers maintain that Chinese trust statistics are comparable with those in the west; they are not inflated.

${ }^{2}$ Further, within the rational choice perspective social relations are reduced to strategic caluculations, i.e., an exclusively economic paradigm is applied to also civil society and politics. Whether this rational actor model of decision-making can be applied even to strictly economic decisions like financial investments has been hotly debated for more than sixty years. Human decision-making relies not only on abstract rational choice models, but is constrained by the limitations on human information
} 
In comparison with other institutions in the local community that could possibly contribute to trusting relationships, the public library stands out as a one of the more open places and as such as a meeting place for diverse traditions (Audunson 2005). This does not mean that there is no room for increasing the libraries' openness by including groups not served well by the library. On the contrary, because of their inclusiveness, and hence, their trust enhancing potential, it is important to know more about how public libraries can be said to create trust, by what specific mechanisms this is supposed to happen. In this paper, I will discuss the role of the public library in creating social trust/social capital from different theoretical perspectives; what perspectives and mechanisms seem most relevant for public libraries? How can libraries develop their trust enhancing capabilities?

The literatures on the generation on social trust and social capital are plentiful. The consensus is that social trust/social capital in the sense of generalized trust/bridging social capital is important for peoples lives, economic development, education, and health (Granovetter 1985; Putnam 1993, 2000; Hutchinson and Vidal 2004; Putnam 2004; Wakefield and Poland 2005). However, empirical studies on public libraries and social capital can be counted on one hand (see Vårheim 2007a). This paper demonstrates how different theoretical perspectives imply different mechanisms for generating social capital and different roles for the public library; mechanisms and roles that need to be taken into account, in the design of policies capable of increasing the contribution of public libraries to social capital in their community. 


\section{Social capital theory}

A definition that comprises most aspects of social capital and that is shared by most scholars, we find in this version by Putnam: "social networks and the associated norms of reciprocity and trustworthiness" (Putnam 2007:137). Social networks are the structural component in the definition. The attitudinal components are norms of trust and reciprocity. For my purposes, I will argue that trust in the form of generalized trust, trust in most people including unknown people, is the part of the definition that expresses the meaning of social capital best. Social networks by themselves neither express trust nor distrust nor horizontal or equal relationships between people (Rothstein and Stolle 2008). Sometimes members of social networks only trust each other. As opposed to generalized trust, this signals particularized trust, trust limited to your own group of people. Networks can also be based upon fear and the existence of external enemies. Trust based solely upon race and ethnicity, and organized crime, are two examples. Corresponding to generalized trust is Putnam's use of the concept of bridging social capital, while particularized trust refers to the same phenomenon as bonding social capital.

There are at least three mainstream theoretical understandings of social capital and its origins widely in use. The first understanding, which we can call the rational choice understanding of social capital, is based on theorists as Bourdieu and Coleman (Bourdieu 1986; Coleman 1990, 1994). Social capital is basically seen as a form of capital like physical, financial, and intellectual capital. Rational actors invest in a specific social relationship in the same way as they do in a specific 
financial asset because they expect the greatest possible return, although not necessarily in the form of money, but also in other forms of capital, e.g. social capital. In this expanded understanding of economic value, social networks are profitable like any other form of capital. As with other investments, trusting others involves a calculation regarding risk versus potential gain (Cook, Hardin and Levi 2005).

The second understanding of social capital, social capital from a societal perspective, is that social capital originates from participation in voluntary associations and informal face-to-face interaction, e.g., in shopping centers, at bus stops, or in public libraries (Putnam 2000; Audunson et al. 2007; Vårheim 2007a). This way, trust, reciprocity, and networks are built.

In the third theoretical understanding of social capital, from the institutional perspective, social capital is created by incorrupt universalistic public institutions, institutions that provide the same benefits to all, e.g. the judicial system, public schools, health and social services, and public libraries (Kumlin and Rothstein 2005; Rothstein and Uslaner 2005; Vårheim 2007a; Rothstein and Stolle 2008; Vårheim et al. 2008).

In the following, I will concentrate on the societal and the institutional perspectives on social capital. The rational choice perspective has little relevance because generalized trust, trust in most people, in unknown people, becomes irrational within this perspective. In a rational choice perspective, strategic actors build trust through social exchanges based on individual self-interest. Trusting 
others is not rational without having specific information about the other that makes her trustworthy, and most people do not have this information about most people (see e.g. Cook et al. 2005). In addition, social actors are not only rational actors; they are also actors within a specific social and institutional context expressing social and institutional norms proscribing rational self-interested action. $^{2}$

\section{Social capital theory and public libraries}

\section{Why study libraries and social capital?}

Early studies done within the societal perspective on social capital maintained that social capital was created by participation in voluntary associations (Putnam 1993). However, people participating in voluntary associations have high social capital before joining; consequently, the finding that voluntary associatons generate social capital among their members is due to self-selection (Stolle 2003). Newer empirical research find little evidence of the effect of voluntary

\footnotetext{
${ }^{2}$ Further, within the rational choice perspective social relations are reduced to strategic caluculations, i.e., an exclusively economic paradigm is applied to also civil society and politics. Whether this rational actor model of decision-making can be applied even to strictly economic decisions like financial investments has been hotly debated for more than sixty years. Human decision-making relies not only on abstract rational choice models, but is constrained by the limitations on human information processing, the problem of ranking of preferences, and conflicting interests (Simon 1947; March and Simon 1958; Cyert and March 1963), by the effects of temporality and other complexities of organizations (March and Olsen 1976), by organizational environments (Meyer and Scott 1983; DiMaggio and Powell 1991; Audunson 1996), and by the history and inertia of institutions (March and Olsen 1989; Steinmo, Thelen and Longstreth 1992; Thelen 2004).
} 
associations on social capital (Delhey and Newton 2005; Rothstein and Stolle 2008). Partly as a result of this, social capital research has turned in two directions. Within the societal perspective, interest has focused upon contact between people through informal interaction as in dinner parties and in the general neighborhood context (Putnam 2000). The second response has been to stress the importance of impartial and universalistic public institutions in the creation of social capital (Kumlin and Rothstein 2005; Rothstein and Uslaner 2005; Rothstein and Stolle 2008). A third response is connecting directly back to voluntary associations seeing them not as an arena first and foremost of informal interaction, but as promoting social capital through their properties as civil society institutions (Wollebæk and Selle 2007).

\section{The societal perspective on social capital generation}

To find out how social capital is generated from a society-oriented perspective, focusing on face-to-face interaction processes has meant that investigating contact between different social groups has become prominent. Ethnic cleavages are among the most pervasive and most difficult social problems. If contact between ethnic groups can increase social capital in society, face-to-face interaction between people across ethnic divisions should create generalized trust. If this test of the interaction hypothesis holds, also contacts that are less problematic would more likely create trust, e.g., interaction between different age grops, social classes, between males and females. However, all in all, most studies conducted show that the level of social capital decreases with ethnic heterogeneity (Alesina \& La Ferrara 2000, 2002; Coffe \& Geys 2006; Costa \& Kahn 2003; Delhey \& Newton 2005; Marschall \& Stolle 2004, 2005; Stolle et al. 2005). 
On the other hand, the characteristics of the interaction situation itself can be important for generating trust. Within social psychology it is maintained that the relationship between contact and generalized trust cannot be expected to be positive unless the interaction meet a set of preconditions: "equal group status within the situation, common goals; inter-group cooperation; and the support of authorities, law, or custom" (Pettigrew 1998). Few contexts can fulfill these ideal conditions. One of the very few candidates that can hope to come close is the public library. This makes the institution of the public library an interesting case for studies of contact through informal face-to-face interaction (Vårheim 2007b).

\section{The institutional perspective on social capital generation}

The institutional perspective on the creation of social capital stresses that impartial, incorrupt, and fair public polices and public institutions enhance trust in policies and institutions and that this trust spills over into generalized trust (Rothstein and Stolle 2003; Rothstein and Uslaner 2005; Rothstein and Stolle 2008). Universalistic public policies and universalistic public institutions that provide the same level of service to everyone regardless of means-testing and therefore with as little stigma as possible, make it possible for everybody to feel being treated as equals and thus being equal members of society. This creates trust in institutions and trust in people in general. Universalistic welfare services (Kumlin and Rothstein 2005; Rothstein and Uslaner 2005), and in particular, equitable and efficient order institutions, the judicial system and the police (Rothstein and Stolle 2008), and public libraries (Vårheim et al. 2008), have shown strong explanatory power in relation to generalized trust. 
A second institutional perspective reintroduces the theme of voluntary associations as creators of social capital (Wollebæk and Selle 2007). Not only public institutions are institutions. Also voluntary associations are institutions. They can be seen as civil society institutions creating trust through their work. It can be argued that the proposed mechanism by which institutional trust is converted into generalized trust pertains to voluntary associations as for public institutions. Findings reveal that the level of generalized trust is the same for passive voluntary organization members as for active members, but that members are more trusting than non-members (Wollebæk and Selle 2007). In countries where people are members of many associations, and where associations are strong and visible, social capital is higher. People that think highly of voluntary associations as instruments for democracy are high trusters, while active participation per se shows no such significant effect. It is mostly through their entrenched institutional values voluntary associations create generalized trust, not as places for contact between individuals. Based on these findings, Wollebæk and Selle conclude that: "strong and visible voluntary organizations demonstrate the utility and rationality of collective action and provide individuals with a democratic infrastructure, which can be activated when needed" (2007:1).

One main obstacle for the validity of the empirical results from the institutional perspective is explaining how the causality on macro-level plays out on microlevel (Vårheim et al. 2008).What are the causal mechanisms generating generalized trust? 
A society without a broad based democratically oriented voluntary sector socializing also relatively passive citizens, with means tested social benefits and the effects of stigmatization on people receiving benefits, and a corrupt order system, may well lead to low trust in public institutions and democracy, and low generalized trust. When people cannot trust public authorities, is it still feasible that they can trust unknown people? On the other hand, broad based organizational societies, and with efficient and impartial public institutions and policies, most likely increase generalized trust.

Reasonable this may be, but without being able to point to and describe the microlevel casual mechanisms that are supposed to create this trust, one cannot really know this. This means it is possible to argue that the opposite causal story is true. A high level of generalized trust and social capital in society lead to universalistic institutions and an organizational society. The causal mechanism needs to be clearly demonstrated before it is possible to conclude regarding the direction of causality; before it possible to conclude whether face-to-face interaction, impartial public institutions, or the organizational society creates generalized trust, or if is in fact generalized trust that creates all these three, that is, generalized trust is the independent variable.

As for the socialization perspective, public libraries become an interesting test case also for the institutional perspective on social capital. Comparatively, the public library is one of the most universalistic institutions there is in that it is open to all, not only people entitled to specific universal benefits as the child benefit (in some countries) or public schooling because they have children, but everyone, 
young and old, black and white. The public library has a wider clientele, in principle every member of society. In this sense, in view of the catchment area of its services the library is more universal than many other universal public services. The library is also more universal in that we find public libraries offering these universal services, if not in every country, we find them across different capitalist models; we find them in the coordinated market economies and welfare states of Western Europe, in the liberal market economies of the US, Australia, UK, Ireland, New Zealand, Canada and Eastern Europe, in the developed economies of the east Asia like Japan, Korea, and Singapore, in Russia, and in Kenya and Malawi. This is not meant to be a complete list of countries and continents. It is just a way of illustrating the worldwide distribution of the universalistic public library model. The fact that we find this universalistic model in so many different contexts and societies also presents a unique opportunity for doing comparative analyses regarding the generation of generalized trust. The possibilities for replication of findings are numerous.

\section{What do we know about public libraries and social capital?}

Little research has been conducted on social capital and public libraries (Vårheim 2007a, b). More has been done on public libraries as social meeting places and instruments for social integration. In early 2006, only three empirically based articles on public libraries and social capital were catalogued in the Web of Science: Elbeshausen and Skov (2004); Caidi and Allard (2005); Hillenbrand (2005). Regarding published books, one chapter of one book found in WorldCat is 
a case study of a branch library's social capital contribution (Putnam, Feldstein and Cohen 2003). The first three of these studies demonstrate how the social capital building effect of public libraries is a spin-off effect of the everyday information services in the libraries. Putnam, Feldstein and Cohen's study shows among other things how the strategic localization of a new library building can instill a feeling of dignity and trust in people that are socially deprived, and create positive contact between people living in segregated neighborhoods.

The most recent studies on what factors create social capital or generalized trust indicate that especially three independent variables have clear effects: Protestant religion, impartial and efficient public institutions, and a broad based “organizational society” (Delhey and Newton 2005; Wollebæk and Selle 2007; Rothstein and Stolle 2008). Perhaps more surprisingly, it turns out that public library spending has an effect on par with the institutional variable, at least within the OECD-countries (Vårheim et al. 2008). Only religion has a stronger effect. Variables like ethnicity and national wealth have smaller and statistically nonsignificant effects.

These results are on the macro-level, and do not say much about what is happening on the ground, about the underlying mechanisms that produce these effects. Without knowledge of what actually happens in the causal stories proposed by the quantitative coefficients, the credibility of the findings always can be questioned. For increasing credibility, numerous case studies of processes of trust generation involving real actors are needed. Lack of such data, that is, qualitative data describing the contents of the trust building process, is typical for 
most social capital research. Interviews with a few public library directors in the US indicate that outreach activities, e.g., ESL-classes (English as a second language classes), directed towards immigrants attracting them to the library create trust in the library that is transformed into at least a lower level of distrust in people in general (Vårheim et al. 2008). Just the fact that it is possible to get these distrusting people into the library is in itself a manifestation of generation of trust and social capital. This is but one example of the data needed.

\section{Conclusion}

Getting vulnerable groups into public libraries is one way of fulfilling the library ideal of being for everybody, of being a truly universal institution. A solid foundation for this work is the high trust in the public library institution expressed by most people, whether users or non-users. Trust creates trust. New library initiatives, strategies and activities, are based upon trust built over time and built into the institution itself. This gives innovative trust building activities in libraries an inherent advantage regarding successful outcomes.

High institutional trust also means that the odds for success becomes lower when the library is offering meeting places for patrons and activities that can create more interaction between diverse groups. Through this kind of interaction, the library can build generalized trust and social capital also from a societal perspective on social capital. Public libraries, more than most contexts, fulfill the conditions of equality in the contact situation. 
Research on social capital and public libraries is important for two main reasons.

On the on hand, the public library provides a unique environment for studying social capital creation processes and thereby for creating new knowledge on these processes. On the other hand, and at the same time, the possible contribution of public libraries in creating social capital is verified and specified. This knowledge is necessary for developing policies, strategies, and activities making public libraries better institutions for creating social capital and as a result better at running their daily business.

\section{References}

Audunson, R.A. (1996). Change processes in public libraries: a comparative project within an institutionalist perspective. Doctoral thesis, University of Oslo, Oslo.

Audunson, R.A. (2005). The public library as a meeting-place in a multicultural and digital context: The necessity of low-intensive meeting-places. Journal of Documentation, 61(3), 429-441.

Audunson, R.A., A. Vårheim, S. Aabø and E.D. Holm. (2007). Public libraries, social capital, and low intensive meeting places Information Research, 12 (4), Retrieved October 17, 2007, from http://informationr.net/ir/124/colis/colis20.html.

Bjørnskov, C. (2006). Determinants of generalized trust: A cross-country comparison. Public Choice, 130(1), 1-21. 
Bourdieu, P. (1986). The Forms of Capital. In John Richardson (Ed.), Handbook of Theory and Research for the Sociology of Education (pp. 241-258). New York: Greenwood Press.

Caidi, N. and D. Allard. (2005). Social inclusion of newcomers to Canada: An information problem? Library \& Information Science Research, 27(3), 302324.

Chen, J. and C. Lu. (2007). Social capital in urban China: Attitudinal and behavioral effects on grassroots self-government. Social Science Quarterly, 88(2), 422442.

Coleman, J.S. (1990). Foundations of social theory. Cambridge, Mass.: Belknap Press.

Coleman, J.S. (1994). A Rational Choice Perspective on Economic Sociology. In Neil J. Smelser and Richard Swedberg (Eds.), The handbook of economic sociology (pp. 166-180). Princeton, NJ; New York: Princeton University Press; Russell Sage Foundation.

Cook, K.S., R. Hardin and M. Levi. (2005). Cooperation without trust? New York: Russell Sage Foundation.

Cyert, R.M. and J.G. March. (1963). A behavioral theory of the firm. Englewood Cliffs, N.J.: Prentice-Hall.

Delhey, J. and K. Newton. (2005). Predicting cross-national levels of social trust: Global pattern or nordic exceptionalism? European Sociological Review, 21(4), 311-327.

DiMaggio, P.J. and W.W. Powell (Eds.). (1991). The New institutionalism in organizational analysis. Chicago: University of Chicago Press. 
Elbeshausen, H. and P. Skov. (2004). Public libraries in a multicultural space: A case study of integration processes in local communities. New Library World, 105(3/4), 131-141.

Granovetter, M.S. (1985). Economic action and social structure: The problem of embeddedness. American Journal of Sociology, 91(3), 481-510.

Hillenbrand, C. (2005). A place for all: social capital at the Mount Barker Community library, South Australia. Australasian Public Libraries and Information Services, 18(2), 41-58.

Hutchinson, J. and A.C. Vidal. (2004). Using social capital to help integrate planning theory, research, and practice. Journal of the American Planning Association, 70(2), 142-192.

Kumlin, S. and B. Rothstein. (2005). Making and breaking social capital: The impact of welfare-state institutions. Comparative Political Studies, 38(4), 339-365.

March, J.G. and J.P. Olsen. (1989). Rediscovering Institutions. The Organizational Basis of Politics. New York: The Free Press.

March, J.G. and J.P. Olsen (Eds.). (1976). Ambiguity and Choice in Organizations. Bergen: Universitetsforlaget.

March, J.G. and H.A. Simon. (1958). Organizations. New York: Wiley.

Meyer, J.W. and W.R. Scott. (1983). Organizational Environments. Beverly Hills, CA: Sage.

Pettigrew, T.F. (1998). Intergroup contact theory. Annual Review of Psychology, 49, $65-85$.

Putnam, R.D. (1993). Making democracy work: Civic traditions in modern Italy. Princeton, N.J.: Princeton University Press. 
Putnam, R.D. (2000). Bowling alone: The collapse and revival of American community. New York: Simon \& Schuster.

Putnam, R.D. (2004). Health by association? Social capital, social theory, and the political economy of public health - Commentary: 'Health by association': Some comments. International Journal of Epidemiology, 33(4), 667-671.

Putnam, R.D. (2007). E Pluribus Unum: Diversity and community in the twenty-first century. The 2006 Johan Skytte Prize Lecture. Scandinavian Political Studies, $30(2), 137-174$.

Putnam, R.D., L.M. Feldstein and D. Cohen. (2003). Better together: Restoring the American community. New York: Simon \& Schuster.

Rothstein, B. and D. Stolle. (2003). Social capital, impartiality and the welfare state: An institutional approach. In Marc Hooghe and Dietlind Stolle (Eds.), Generating social capital: Civil society and institutions in comparative perspective (pp. 191-210). New York: Palgrave Macmillan.

Rothstein, B. and D. Stolle. (2008). The state and social capital - An institutional theory of generalized trust. Comparative Politics, 40(4), 441-459.

Rothstein, B. and E.M. Uslaner. (2005). All for all: Equality, corruption, and social trust. World Politics, 58(1), 41-72.

Simon, H.A. (1947). Administrative behavior: A study of decision-making processes in administrative organization. New York: The Macmillan Company.

Steinmo, S., K. Thelen and F. Longstreth (Eds.). (1992). Structuring Politics: Historical Institutionalism in Comparative Analysis. Cambridge: Cambridge University Press. 
Stolle, D. (2003). The sources of social capital. In Marc Hooghe and Dietlind Stolle (Eds.), Generating social capital: Civil society and institutions in comparative perspective (pp. 19-42). New York: Palgrave Macmillan.

Thelen, K.A. (2004). How institutions evolve: The political economy of skills in Germany, Britain, the United States, and Japan. Cambridge: Cambridge University Press.

Uslaner, E.M. (2002). The moral foundations of trust. New York: Cambridge University Press.

Uslaner, E.M. (2006). Does diversity drive down trust? Retrieved Date Accessed, from http://ssrn.com/abstract=903051.

Vårheim, A. (2007a). Social capital and public libraries: The need for research. Library \& Information Science Research, 29(3), 416-428.

Vårheim, A. (2007b). Social capital and the multiethnic challenge: The role of the public library. In Rashmi Sharma (Ed.), Social Capital: An Introduction (pp. 100-110). Hyderabad: ICFAI University Press.

Vårheim, A., S. Steinmo and E. Ide. (2008). Do Libraries matter? Public libraries and the creation of social capital. Journal of Documentation, 64(6).

Wakefield, S.E.L. and B. Poland. (2005). Family, friend or foe? Critical reflections on the relevance and role of social capital in health promotion and community development. Social Science \& Medicine, 60(12), 2819-2832.

Wollebæk, D. and P. Selle. (2007). Origins of social capital: Socialization and institutionalization approaches compared. Journal of Civil Society, 3(1), 1-24.

World Values Survey. (2006). European and world values surveys four-wave integrated data file, 1981-2004. Retrieved October 29, 2006, http://www.jdsurvey.net:8080/bdasepjds/wvsevs. 


\section{Acknowledgements}

I thank the participants in the IFLA conference (see below) and one anynomous reviewer for comments to an earlier version. This paper is written as part of the research project "PLACE: Public Libraries - Arenas for Citizenship" funded by the Research Council of Norway. An earlier version of the paper was presented at the Library Theory and Research Section, World Library and Information Congress: 74th IFLA General Conference and Council, 10-14 August 2008, Québec City, Québec, Canada. 